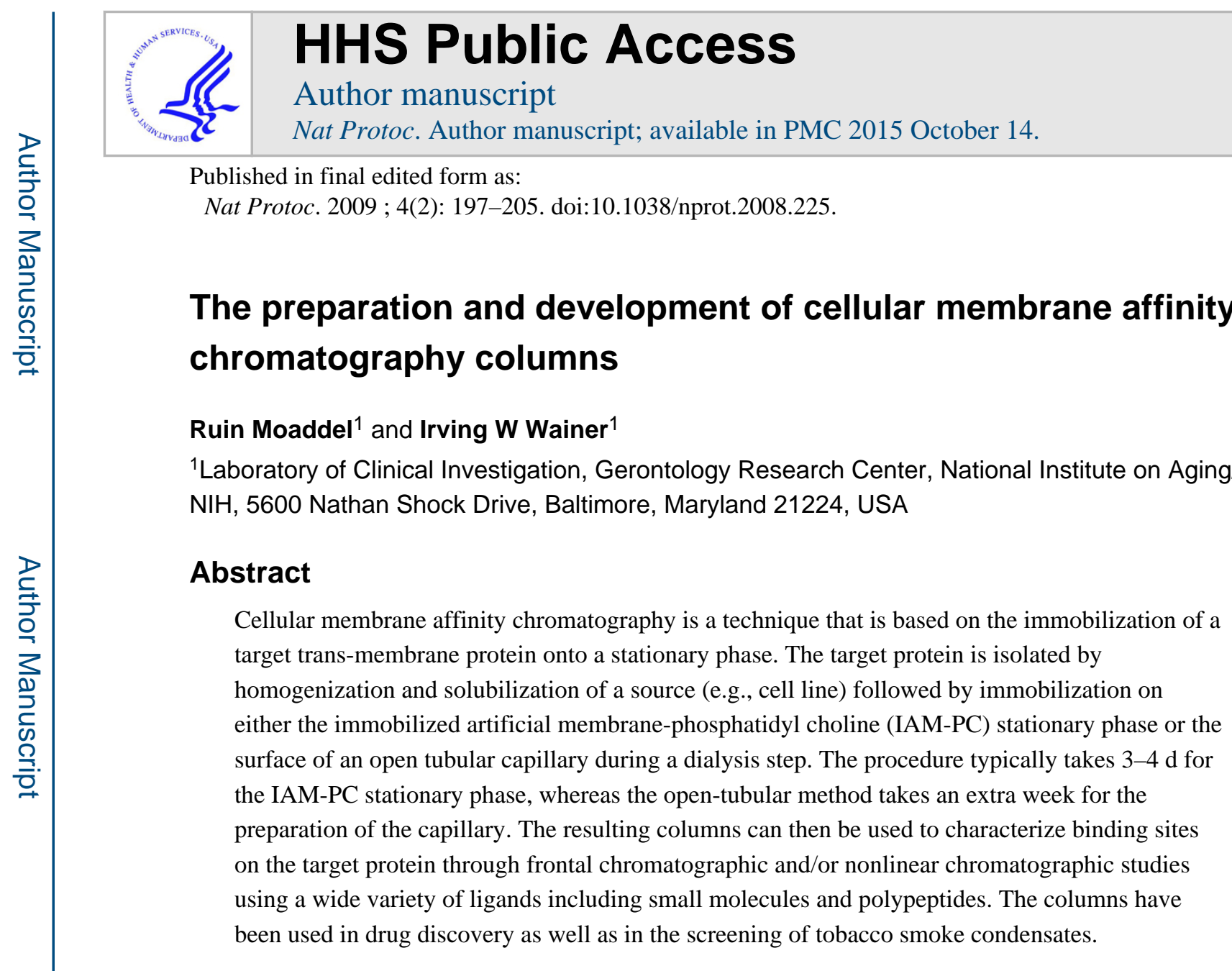

\title{
INTRODUCTION
}

In a recent article in this journal, Schriemer and colleagues ${ }^{1}$ described a biophysical method for the discovery and characterization of molecular interactions in a flow system, frontal affinity chromatography (FAC). In the review, they clearly and precisely described the theoretical and experimental approaches to FAC. Although they concentrated on the use of immobilized enzymes and carrier proteins in FAC, they also indicated that cells, cell fragments or membrane-bound protein can be immobilized and incorporated into a FAC system. This article will address the latter issue and describe the development and characterization of cellular membrane affinity chromatography (CMAC) columns that can be used in FAC and nonlinear chromatography (NLC) studies.

\section{CMAC columns}

The incorporation of isolated cytosolic proteins and enzymes into an affinity chromatography column and the application of the resulting column to the study of ligandprotein interactions was first demonstrated by Chaiken ${ }^{2}$ and $\mathrm{Carr}^{3}$ and has been extensively studied (cf. refs. 4 and 5). Initially, the immobilization of the proteins was carried out by 'random' chemical cross-linking reactions. Although this method worked, it resulted in a

Reprints and permissions information is available online at http://npg.nature.com/reprintsandpermissions/ Correspondence should be addressed to R.M. (moaddelru@mail.nih.gov).. 
significant loss of activity, which for commercially available or readily accessible proteins is not a great deterrent. However, when working with transmembrane proteins, this becomes a rate-limiting process, as these proteins are usually not available in a purified form.

The first immobilization of a transmembrane protein was carried out by Lundahl's group. In these studies, the glucose transporter, GLUT1, was immobilized through the incorporation of red blood cell membranes in proteoliposomes and the resulting column was used in the online study of glucose transport ${ }^{6,7}$. On the basis of Lundahl's initial work, cellular membranes obtained from an HEK293 cell line expressing the a3a4 nicotinic acetylcholine receptor (nAChR) were entrapped in lipid monolayers and used to measure ligand binding to the $\mathrm{nAChR}$ using $\mathrm{FAC}^{8}$. The chromatographically determined affinities were comparable with affinities obtained using standard membrane-binding techniques, such as filtration assays, demonstrating that the FAC approach could be used to study binding interactions with immobilized transmembrane receptors.

In the same series of experiments, the cellular membrane fragments from the HEK293 cell line expressing $\mathrm{nAChR}$ were also immobilized on a liquid chromatographic stationary phase, the immobilized artificial membrane (IAM) stationary phase developed by Pidgeon $e t$ $a l .{ }^{9}$. No significant difference was observed between the binding data obtained using the liposomal and IAM-based columns ${ }^{8}$. Membranes containing nAChRs have also been immobilized in chromatographic systems through encapsulation with a polymer and the resulting columns used in $\mathrm{FAC}^{10}$.

On the basis of the initial studies with the HEK293 cell line, it was determined that the commercially available IAM support was easier to handle and the resulting columns more reproducible than the liposomal column. Thus, the IAM stationary phase has been used to create a series of CMAC columns from a variety of cell lines. The resulting columns have been used to study G-protein coupled receptors (GPCRs), including $\kappa$ and $\mu$ opioid $^{11}, \beta_{2}-$ adrenergic $^{12}$ and $\mathrm{P}_{2} \mathrm{Y}_{1}$ purinergic ${ }^{13}$ receptor, ligand-gated ion channels (LGICs), such as $\mathrm{nAChRs}{ }^{8,14}$, and transmembrane drug transporters, such as P-glycoprotein (Pgp $)^{15}$, human organic cation transporter-1 (hOCT1) ${ }^{16}$ and human organic anion transporter 1 and 2 (OAT1, OAT2 $)^{17}$. A multiple LGIC-CMAC column containing coimmobilized nAChRs, $\gamma$ amino-butyric acid $\left(\mathrm{GABA}_{\mathrm{A}}\right)$ and $N$-methyl-D-aspartate (NMDA) receptors have also been created through the immobilization of solublized brain tissue ${ }^{18}$. Membranes from a cell line that expresses Pgp and one that does not have also been used to create open tubular columns $(\mathrm{Pgp}(+)-\mathrm{OT})$ where they were used with FAC to rapidly identify Pgp substrates, including small molecules and polypeptide inhibitors ${ }^{19}$.

\section{When should I consider using a CMAC column?}

The CMAC technique is best suited for use in a number of stages of the drug-discovery process including initial screening of complex mixtures to identify ligands to a target membrane protein and in the adsorption, distribution, metabolism and excretion stage of the process. In addition, this approach can be used to investigate and describe the interactions of small molecules and proteins with the target membrane protein ${ }^{13-20}$. Other methods that can be used to study membrane protein-ligand interactions include filtration assays, binding assays and functional studies. These methods can be used to cross-validate a new CMAC 
column and can be replaced by the chromatographic approach once the CMAC column has been characterized. In addition, allosteric inhibitors are difficult to identify using standard binding assays, but are readily determined using the CMAC.

The CMAC technique has been recently used in the online screen of tobacco smoke condensates to identify nAChR ligands contained in the matrix ${ }^{20}$. In these studies, a CMAC column prepared from a cell line expressing the $a 3 b \beta n A C h R(C M A C(a 3 \beta 4 n A C h R)$ ) was used to identify fractions within the condensates that contained compounds that bound to the nAChR. Chemical libraries have also been screened. For example, a series of anabasine derivatives were chromatographed on CMAC $(a 3 \beta 4 \mathrm{nAChR})$ and CMAC ( $\alpha 4 \beta 2 \mathrm{nAChR})$ columns to determine their relative affinities to the receptors ${ }^{18}$. A single FAC study using displacement of a marker ligand was able to rank the test compounds by their affinities within and between the two nAChR subtypes.

In the adsorption, distribution, metabolism and excretion stage, CMAC columns containing the target protein can be used to characterize the relative extent and type of binding of lead drug candidates. For example, a CMAC ( $(23 \beta 4 \mathrm{nAChR})$ column has been used to differentiate between $\mathrm{nAChR}$ agonists, competitive antagonists and noncompetitive inhibitors (allosteric modifiers), to determine the binding affinities of these ligands as well as the sites at which they bind ${ }^{21,22}$. The approach was also used to predict the $\mathrm{IC}_{50}$ values of noncompetitive inhibitors and the relative duration of receptor inhibition produced by the inhibitors after a single injection on the CMAC column ${ }^{22}$.

Cellular membrane affinity chromatography columns can also be used to determine the drug transporter-mediated adsorption and elimination of a compound. Pgp(+)-OT and Pgp(-)-OT columns were used with FAC to rapidly identify Pgp substrates. The chromatographic results correlated with those obtained using the industry standard monolayer efflux assays. In addition to a strong correlation, the CMAC assay had a high if not higher throughput than the alternative cell-based assays ${ }^{23}$. CMAC columns containing hOCT1, hOAT1 or hOAT2 can be used to identify substrates and inhibitors of these transporters as well as the stereoselectivity of the interactions ${ }^{16,17,24}$.

Cellular membrane affinity chromatography columns can also be used in basic pharmacological studies to characterize the binding process to a target. For example, a CMAC(a334 nAChR) column and NLC techniques were used to study the thermodynamics of the binding of noncompetitive inhibitors to binding sites within the central lumen of the receptor $^{25}$. NLC techniques were also used with CMAC( $\left.a 3 \beta 4 \mathrm{nAChR}\right)$ and CMAC(a332 $\mathrm{nAChR}$ ) columns to guide the development of molecular models of the central lumen of both receptors in which a key binding site was identified and the ligand-binding process was defined ${ }^{26}$.

A CMAC(hOCT1) column and FAC studies were also used in the development of a molecular model that described the binding of competitive inhibitors with the transporter ${ }^{24}$. This model was able to depict a chiral recognition model that explained the observed enantioselective inhibition of hOCT1 transport. 


\section{Is my transmembrane target suitable for a CMAC column?}

As a first approximation, the CMAC approach is similar to standard membrane-binding techniques. Thus, if your target can be studied by routine pharmacological procedures, then you can expect to be able to develop and use a CMAC column. The breadth of the method is illustrated by the fact that, to date, we have immobilized a large array of transmembrane proteins, including ligand gated ion channels such as five subtypes of the nAChR, NMDA and $\mathrm{GABA}_{\mathrm{A}}$ receptors ${ }^{22}$, drug transporters such as Pgp, hOCT1, hOAT1 and hOAT2 as well as GPCRs such as the $\mu$ and $\kappa$ opioid receptors, $\beta$-adrenergic receptors, $\mathrm{P}_{2} \mathrm{Y}_{1}$ receptor and more recently the histamine 1 receptor (R.M., I.W.W., unpublished data).

\section{Should I use a transfected or native cell line?}

Although transfected cell lines are a reliable source of proteins, other adequate sources include tissues, e.g., rat brain, and endogenous cells (Table 1). In the latter cases, these sources are advantageous when studying multiple proteins on a single column ${ }^{27}$.

Using a transfected cell line-One of the major reasons for using a transfected cell line is the increased expression of the target protein, and this is important if the CMAC column is going to be used in the drug discovery process. This is due to the fact that in the development of the CMAC column, the target proteins are not isolated from the membrane and purified. Thus, the number of active sites on a CMAC column depends upon the number of active proteins contained within the membrane. Therefore, the use of a cell line in which the target has been 'overexpressed' usually increases the capacity and selectivity of the resulting column.

The lack of purification of the target protein appears to help retain protein function as well as to stabilize the immobilized target ${ }^{28}$. However, membranes contain hundreds, if not thousands, of other proteins that may bind the same ligands as the target. Thus, FAC curves may represent a combination of specific and non-specific interaction, thereby incorrectly reflecting the binding affinity of a test ligand. One way to minimize this problem is to use a target-specific marker ligand. For example, if binding to the $\mathrm{nAChR}$ is the goal of the FAC experiments, epibatidine would be the ideal specific marker.

However, if a specific marker does not exist, or if the specificity has not been adequately established, the best approach is to use a cell line that does not contain the target to control off-target and nonspecific binding. The closer the basic membrane structure, the better the control. If a transfected cell line is used to create the CMAC column, the best control is the nontransfected cell line.

The use and necessity of control columns was demonstrated by the use of the Pgp(+)-OT (experimental column) and Pgp(-)-OT (control column) to identify Pgp substrates ${ }^{19,23}$. Both columns were created using LCC6 cells, in which the source of the Pgp(-)-OT was the nontransfected LCC6 cell line and the Pgp(+)-OT was derived using the LCC6 cell line after it had been transduced with the retroviral vector carrying the cDNA for the mdr1 (Pgp) gene $^{29}$. The screening was carried out using FAC without a Pgp-marker ligand on both the control and experimental columns. The results indicated that it was necessary to subtract the 
retention time observed on the $\mathrm{Pgp}(-)$-OT from the retention time observed on the Pgp(+)OT. The calculated $\Delta t$ values of the test compounds correlated with the results obtained using a Caco- 2 cell-based monolayer efflux assay and substrates could be readily identified $^{23}$.

Using a native cell line-Whereas using transfected cell lines is a way to increase the number of active binding sites on a CMAC column, the use of a wild-type cell line has the advantage of providing the target protein in its native environment with the proper posttranslational modifications. In the latter instance, after a protein has been synthesized, it is often modified through one or more pathways, including methylation, phosphorylation, acetylation, removal of $\mathrm{N}$-terminal amino-acid moieties and oxidation or reduction of disulfide bonds that produce the active form of the protein ${ }^{30}$. When the target protein is synthesized by a cell line that does not naturally produce it, there is no guarantee that the posttranslational modifications in the protein will be the same as those found in the native cell line.

If the goal of the research program is to study the biological function of the target, then native cells are the preferred source of the CMAC system. The use of the native cells also ensures that the protein will be in a lipid environment that allows for the proper functioning of the channel and that it will be associated with other proteins that may be vital for biological function. Our initial studies of the characterization of CMAC columns made from a nontransfected $1321 \mathrm{~N} 1$ cell line have demonstrated that the number of nAChRs expressed in the cell line was adequate for the development of a functioning CMAC(nAChR) column ${ }^{27}$. In addition, the resulting column has also been shown to contain other LGICs, e.g., NMDA and $\mathrm{GABA}_{\mathrm{A}}$ receptors, which could also be characterized and used in FAC studies $^{27}$.

\section{Can I use my cell line?}

To date, we have CMAC columns that have been created using cell lines derived from human, canine and hamster sources (Table 1). Therefore, it is most likely that any mammalian-derived cell line will work. However, as the composition and structure of cellular membranes differ from cell line to cell line, this fact has to be taken into consideration in the solubilization and immobilization protocols used in the preparation of the CMAC columns (see Tables $\mathbf{1}$ and $\mathbf{2}$ ). This is illustrated by the development of two $\mathrm{CMAC}(\mathrm{a} 7-\mathrm{nAChR})$ columns $^{28}$. The membranes used to create the columns were obtained from two cell lines, SH-EP1 and HEK-293, each of which had been transfected with cDNA for the a7nAChR. The CMAC column prepared from the membranes obtained from the SHEP1 cell line required the presence of cholesterol, phosphatidyl serine and phosphatidyl ethanolamine in the solubilization buffer, whereas the buffers used in the preparation of the CMAC column containing HEK-293 membranes required only the presence of cholesterol.

\section{Should I use FAC or nonlinear chromatography?}

FAC-Frontal affinity chromatography can be used to characterize the binding of small molecules to an immobilized membrane-bound target and to determine binding affinities $\left(K_{\mathrm{d}}\right)$ and the number of active binding sites on the column $\left(\mathbf{B}_{\max }\right)$. A detailed review of the 
FAC technique has been published recently by $\mathrm{Ng}$ et al. ${ }^{1}$, and this approach will not be discussed here in detail. A key requirement of FAC is the existence of a compound that is known to bind to the target, the marker ligand. In FAC, the marker ligand is placed in the mobile phase and passed through the column.

A typical frontal chromatogram is presented in Figure 1a and represents the addition of $\left[{ }^{3} \mathrm{H}\right]$-labeled epibatidine $\left(\left[{ }^{3} \mathrm{H}\right]-\mathrm{EB}\right)$ to the mobile phase running through the CMAC $(\alpha 3 \beta 4$ $\mathrm{nAChR}$ ) column ${ }^{8}$. Displacement studies with increasing concentrations of EB and nicotine are also presented (Fig. 1a).

The relationship between displacer concentration and retention volume can be established using Equation 1 and can be used to determine the $K_{\mathrm{d}}$ value of the displacer and the number of active binding sites on the column, $B_{\max }$.

$$
[D i s]\left(V-V_{\min }\right)=P[D i s]\left(K_{d D i s}+[D i s]\right)^{-1}
$$

where $P$ is the product of $B_{\max }$ and $\left(K_{\mathrm{dDis}} / K_{\mathrm{dMarker}}\right), V$ is retention volume of $\mathrm{EB}, V_{\min }$ is the retention volume of $\mathrm{EB}$ when the specific interaction is completely suppressed (this value can be determined by running $\left[{ }^{3} \mathrm{H}\right]$-EB with a high concentration of displacer). From the plot of [EB] $\left(V-V_{\min }\right)$ versus [EB], dissociation constant value, $K_{\mathrm{d}}$, for EB can be obtained as well as the number of binding sites for EB on the column $\left(B_{\max }\right)$. To have a functional column, there needs to be sufficient number of binding sites to allow detection of the marker ligand, either by radio-flow chromatography or mass spectrometry.

NLC-Nonlinear chromatography can be used also to determine dissociation constants, as is done in FAC (Table 3). However, the greatest advantage of NLC lies in the ability of this method to study the kinetics and thermodynamics of the interaction of small molecules with the target protein. In this approach, the observed concentration-dependent asymmetry (see Fig. 1b) is analyzed using chemometric curve-fitting techniques and used to calculate the association rate constant $\left(k_{\text {on }}\right)$, dissociation rate constant $\left(k_{\text {off }}\right)$ for the ligand-receptor complex and the equilibrium constant for complex formation $(K)$.

One approach to the analysis of NLC data is the impulse input solution for the mass balance equation developed by Wade et al. ${ }^{31}$. This approach is based upon the observation that when adsorption/desorption rates are slow, band broadening is insensitive to a moderate degree of column overload. In contrast to numerical integration methods, this approach uses the analytical solution, which can be applied directly to fit experimental peak profiles. The impulse input equation has been included in commercially available deconvolution softwares, such as Peak Fit v. 4.11 for Windows software available from SPSS Inc., and can be applied easily to NLC studies. The parameters used to describe the chromatographic peak and their use in the calculation of thermodynamic and kinetic constants are summarized by Jozwiak et al. ${ }^{25}$.

Alternative approaches-Another approach is to use zonal chromatography, in which a small sample volume is injected onto the chromatographic column as opposed to frontal chromatography where the analyte is in the mobile phase and the conditions are under 
dynamic equilibrium or NLC where the analyte is injected near or at target saturation. In zonal chromatography, a retention time of a compound is comparable with its affinity for the target. Although beneficial, the chromatographic efficiency of the column is too low to adequately resolve a mixture of compounds on the basis of their relative affinities.

Therefore, it may be necessary to use multidimensional chromatographic systems. These coupled systems have been reported previously ${ }^{32}$. For example, a mixture of binders and nonbinders were sorted on the basis of their affinity for the a $3 \beta 4-n A C h R$ and were then transferred to the $\mathrm{C} 18$ column for separation and identification. Of the 18 compounds tested, 7 were identified correctly as ligands of the nicotinic receptor and 11 were correctly identified as nonbinders ${ }^{32}$. Subsequently, tobacco smoke condensates were screened using a similar multidimensional chromatographic system ${ }^{20}$ in conjunction with missing peak chromatography. This technique correctly identified seven known compounds and identified a number of potentially unidentified compounds, demonstrating the advantage of using this method for the screening of complex chemical mixtures.

In addition, we have shown previously that protein-coated magnetic beads can be successfully used to separate small-molecule binders from nonbinders ${ }^{33,34}$, as well as proteins from cellular extracts ${ }^{34}$. Preliminary studies with magnetic beads coated with cellular membranes from the KXa3 $\beta 4 \mathrm{R} 2$ cell line expressing the a $3 \beta 4 \mathrm{nAChR}$ demonstrate that transmembrane proteins can also be studied in this manner (R.M., unpublished data).

The advantages and disadvantages of each of these methods have been summarized in Table 4.

\section{Key parameters in the development of the CMAC column}

As discussed below, there are several parameters that need to be considered (including cell lines, receptor type, expression of the receptor) that influence the choice of homogenization and solubilization buffers as well as the mobile phase composition. In our laboratory, we have characterized immobilized targets using radio-labeled ligands detected using an online radio-flow detector. However, if a radio-flow detector is unavailable, the system could be adapted to mass spectrometry or optical detection including UV and fluorescence. Typically, we are working with transfected cell lines, in which case we have a positive control (the nontransfected cell line), a negative control (the IAM stationary phase) and our CMAC column from the transfected cell line. When native cells are used, then biologically or chemically altered cell lines can be used as a positive control. Once the column has been established, two replicates are sufficient to establish meaningful affinities.

Finally, in deciding whether to immobilize the target protein on the IAM stationary phase or the open tubular capillary, a few points should be considered. If the ligands that bind to the target protein are hydrophilic, then the IAM stationary phase should suffice; however, if they are lipophilic, we suggest opting for the open tubular capillary. This is mainly due to the large amount of nonspecific binding observed between the ligand and the IAM stationary phase. On the other hand, if the target membrane protein is not highly expressed on the surface of the cell, then the IAM stationary phase should be used for immobilization, as a much larger surface area will allow detection of proteins expressed at much lower levels. 
In the PROCEDURE, we provide details for immobilization on the IAM stationary phase. For details on how to immobilize in open tubular capillaries, please refer to Box $\mathbf{1}$.

\section{MATERIALS REAGENTS}

- Radioactive marker ligands, dependent on the target receptor (Amersham Biosciences or NEN Life Science Products)

- $\quad$ 12- $\mu$ m IAM-PC stationary phases (Regis Technologies Inc.)

- Open tubular capillaries (100 $\mu$ m i.d.; Polymicro Technologies)

- Unlabeled ligands that are selective for the target receptors/transporter (SigmaAldrich)

- Protease inhibitors dependent on cell line (Sigma-Aldrich)

- $20 \mathrm{~cm} \times 100 \mu \mathrm{m}$ i.d. open tubular capillaries (Polymicro Technologies)

- Dialysis tubing, Snake skin pleated dialysis tubing with 10,000 MWCO (Pierce)

- Biotin-X (6-[(biotinoyl)amino]hexanoic acid) from (Sigma, cat. no. B-7181; Sigma-Aldrich)

\section{EQUIPMENT}

- IN/US $\beta$-ram Model 3B Radio-flow detector (IN/US Systems)

- Shimadzu LC-10 ADvp pump (Shimadzu)

- $1 \mathrm{ml} \times 50 \mathrm{ml}$ superloop (Amersham Biosciences, cat. no. 19-5165-01)

- 1 rabbit peristaltic pump (Rainin, cat. no. 7103-052)

- 1 HR 5/20 Tricorn Amersham column (Amersham Biosciences, cat. no. 18-1163-08)

- For mass spectrometric studies only: Agilent LC-MSD (Agilent) in positive electrospray mode with single-ion monitoring with the following settings: drying gas flow: 11 liter $\mathrm{min}^{-1}$; nebulizer pressure: $35 \mathrm{psig}$; fragmentor voltage: $70 \mathrm{eV}$; capillary voltage: $3,000 \mathrm{~V}$; drying gas temperature: $350{ }^{\circ} \mathrm{C}$

\section{REAGENT SETUP}

Cell lines Which cell line? Once the target membrane protein(s) have been selected, the key issue is selecting a cell line that expresses the target. An ideal source is a transfected cell line (Table 1). A wide variety of cells have been used. The homogenization and solubilization buffer are dependent on the cell line. $\triangle$ CRITICAL The choice of cell line will influence the makeup of the homogenization and solubilization buffer, as will the receptor choice. How many cells? To carry out a successful immobilization, a minimum amount of the targeted protein needs to be immobilized. When using transfected or endogenous cells, the amount needed can be determined only empirically. We typically start from 10 million cells and adjust accordingly. For example, the heteromeric subtypes of the nicotinic receptor 
required only 1 million cells of the transfected cell line, whereas the PGP transporter required 50 million cells for a detectable amount of immobilized protein. Homogenization buffer The homogenization buffer must contain salts, protease inhibitors and peptidase inhibitors to prevent degradation of the target protein. The choice of protease inhibitors is dependent on the cell line being used; determine which proteolytic enzymes are present in your cell and target them appropriately. The list of protease inhibitors that we have commonly used are as follows: leupeptin, pepstatin, aprotinin, tosyl-amido-2-phenylethylchloromethyl ketone, phenyl methyl sulfonyl fluoride, benzamidine and calpain ${ }^{11-29}$. For example, to obtain a functioning hERG channel column (R.M., unpublished data), the addition of aprotinin, leupeptin and pepstatin was required. The absence of aprotinin would result in a nonfunctional column. In addition, if metalloproteases are present, the addition of EDTA or EGTA would be required to inhibit these proteases. $\triangle$ CRITICAL The simplest way to determine which protease inhibitors are required for a particular cell line is through a literature search. Solubilization buffer For the solubilization buffer, the most important aspect is the choice of detergent. Typically, the detergent should have a low aggregate number per micelle and a high CMC; in this way, the micelles should be relatively easy to disrupt (i.e., dialysis should be capable of removing the detergent). This eliminates the use of stronger detergents such as Triton X-100 and Tween. Although these detergents can now be more readily removed using Biobeads, we have found that the time and conditions required for the removal of these detergents were too harsh for transmembrane proteins and predominantly resulted in nonfunctioning columns. For the majority of our studies, we have limited our choice to three detergents: CHAPS, cholate and $\beta$-octyl glucopyranoside. The first two seem to be specific in the type of receptors they immobilize. For example, we have found that CHAPS should be used for the immobilization of GPCRs, whereas cholate seems to preferentially solubilize ligand-gated ion channels. $\beta$-Octyl glucopyranoside is the strongest of these three detergents and does not seem to preferentially solubilize one class of receptors over the other. This does not mean that the protocol is limited to these three detergents, as there are many others that fit the criteria for a plausible detergent. However, these three detergents have been successfully and reliably used in our laboratory. In addition to the detergent, some proteins require the addition of glycerol to stabilize the protein during the immobilization process (Fig. 2) ${ }^{35}$. Although this has to be empirically determined, we have found that the addition of $10 \%$ ( $\mathrm{vol} / \mathrm{vol}$ ) glycerol to the solublization buffer enhances the stability of the target protein ${ }^{35}$. Finally, in some cases, the protein stability is highly dependent on the lipid environment. In this case, the addition of lipids and/or cholesterol may be necessary ${ }^{28}$. FAC running buffer Once the column is ready to be run, the running buffer for frontal chromatographic studies needs to be determined. In the majority of cases, we start with ammonium acetate $(10 \mathrm{mM}, \mathrm{pH} 7.4)$, as it is ideal for mass spectrometry, and make modifications to this buffer. The additives in the running buffer are solely determined by the protein that was immobilized and the objective of the additive. For example, with the hOCT1 and hOATs, both members of the solute carrier superfamily, it was required to add $\mathrm{MgCl}_{2}$ and $\mathrm{CaCl}_{2}$ to the mobile phase for proper functioning of the transporters. Although this did not present a problem for the frontal chromatographic studies on the radio-flow detector, it could present a problem for detection by mass spectrometry. On the other hand, when our objective was to reduce the retention time of the ligands, we added methanol to the mobile phase (up to $15 \%$ for the nicotinic receptor; typically less than 10\%). Careful 
consideration should be taken when adding methanol to the mobile phase, as it could cause a change in the lipid aggregate structure and result in loss of stability of the transmembrane protein and reduce the lifetime of the column. When the NMDA receptor was the target, it was necessary to add the cofactors glutamate and glycine to the mobile phase to ensure the proper functioning of the channel. Therefore, for the running buffer, the best approach is to carry out a literature search to determine what additives/cofactors are required for the proper functioning of the target protein and then to make the appropriate adjustments to the mobile phase. Stationary phases We predominantly use the IAM-PC stationary phase for noncovalent immobilization of the target protein. For the open tubular columns, we immobilize transmembrane proteins through the biotin-avidin system, whereas cytosolic proteins are immobilized covalently. Marker ligand selection The ideal marker ligand has high affinity and selectivity for the target protein. If this is not available, parallel screening with a control column is necessary.

\section{EQUIPMENT SETUP}

FAC system assembly The frontal chromatographic system was set up as displayed in Figure 3.

\section{PROCEDURE}

\section{Homogenize and solubilize cells - TIMING $\sim 1 \mathrm{~h}$ for homogenization, $18 \mathrm{~h}$ for solubilization}

1| Homogenize the required number of cells (REAGENT SETUP) using an appropriate buffer (REAGENT SETUP) and method. The cells should be suspended in $10 \mathrm{ml}$ of buffer. Typically, we homogenize the cells using a polytron homogenizer $(3 \times 10 \mathrm{~s}$ at the setting of 15 on a Model PT-2100 homogenizer (Kinematica AG)). However, some cells are more sensitive to certain homogenization methods than others. For example, when the AMPA receptor was immobilized, the polytron homogenizer was too vigorous and resulted in a nonfunctional column. In this case, the cells were homogenized using a sonicator. For more sensitive proteins, a glass-dounce homogenizer can be used.

2| Once homogenized, centrifuge the homogenate at $450 \mathrm{~g}$ for $7 \mathrm{~min}$ at $4{ }^{\circ} \mathrm{C}$ and discard the pellet containing the nuclear proteins.

$3 \mid$ Next, centrifuge the supernatant at $100,000 \mathrm{~g}$ for $35 \mathrm{~min}$ at $4{ }^{\circ} \mathrm{C}$ and collect the resulting pellet containing the cellular membranes.

4| Resuspend the pellet in the prepared solubilzation buffer (see REAGENT SETUP, $10 \mathrm{ml}$ ) and rotate the resulting mixture at 150 r.p.m. on an orbital shaker (Lab-line Model 3520, Melrose Park) for $18 \mathrm{~h}$ at $4{ }^{\circ} \mathrm{C}$.

5| Centrifuge the resulting solution at $90,000 \mathrm{~g}$ for $25 \mathrm{~min}$ at $4{ }^{\circ} \mathrm{C}$, discard the pellet and suspend the supernatant in $200 \mathrm{mg}$ of the IAM stationary phase.

\section{Immobilize on the IAM support through dialysis - TIMING 1-3 d}

6 Gently rotate the resulting suspension of the IAM stationary phase and the supernatant at $25^{\circ} \mathrm{C}$ for $90 \mathrm{~min}$ at 150 r.p.m. on an orbital shaker. 
7| Transfer this solution to a dialysis tube containing the IAM-PC stationary phase, and dialyze at $4{ }^{\circ} \mathrm{C}$ for a period of 24,48 or $72 \mathrm{~h}$ against 1 liter of dialysis buffer with gentle rotation. Replace the dialysis buffer every $24 \mathrm{~h}$. Typically, $24 \mathrm{~h}$ should be sufficient to disrupt the micelles and remove the majority of the detergent, allowing the solubilized protein to adsorb onto the IAM stationary phase. However, it has been found that the maximum immobilization occurs with $48 \mathrm{~h}$ dialysis. If the solubilized protein is not very stable, an 18 -h dialysis is recommended.

8| After dialysis, wash the stationary phase three consecutive times with Tris buffer $(10 \mathrm{mM}$, $\mathrm{pH}$ 7.4) and centrifuge at $700 \mathrm{~g}$ for $3 \mathrm{~min}$ at $4{ }^{\circ} \mathrm{C}$ between washes.

\section{Column packing $\odot$ TIMING $15 \mathrm{~min}$}

9| After washing, pack the stationary phase into an HR 5/2 column. Typically, the IAM stationary phase is hand-packed into an HR 5/2 Tricorn column from Amersham, following the instructions provided with the column. However, the protein-immobilized stationary phase can also be packed using a pressure bomb. In our laboratories, packing the a $3 \beta 4$ NRIAM stationary phase by pressure bomb did not result in any loss of activity ${ }^{8}$.

PAUSE POINT For long-term storage (longer than $3 \mathrm{~d}$ ), the column is stored with $0.1 \%$ sodium azide.

\section{Chromatographic system - TIMING Dependent on ligand/protein interactions; ranges from $30 \mathrm{~min}$ to $3 \mathrm{~h}$}

10| Connect the column to a Shimadzu LC-10 AD pump (Fig. 3), to a superloop (for frontal chromatographic studies) and then to a detector.

11| When ready to start the experiment, load the superloop with the radioactive marker using a rabbit peristaltic pump. In the case of IAM-based columns, the flow rate typically used is between 0.2 and $0.5 \mathrm{ml} \mathrm{min}^{-1}$, whereas for the open tubular capillaries, the flow rate is at 50 $\mu \mathrm{min}^{-1}$. In both cases, the experiments are carried out at room temperature $\left(25^{\circ} \mathrm{C}\right)$ unless thermodynamic studies are being undertaken. The columns can be studied using different equipment. The Radio-flow detector ( $\beta$-Ram IN/US) is used to detect the marker ligand, and the displacement is measured by increasing concentration of the unlabeled displacer. If radioactive studies are not possible, a mass spectrometer, UV detector or any other detector can be used in place of the radio-flow detector. For mass spectrometery, an easily detectable ligand would be required and necessary adjustments to the mobile phase should be made to avoid problems with the mass spectrometer, e.g., phosphate buffers and Tris buffers have to be avoided. $\triangle$ CRITICAL STEP To determine that the activity of the column has not changed over time, we suggest running one concentration of your marker ligand at the start of every week and monitor the retention volume. The immobilized proteins are conformationally mobile between different states; therefore the loss of activity can sometimes be regenerated by exposing the column to an agonist that induces the required conformational change. However, when loss of activity is observed, it is typically better to make a new column than to attempt regeneration.

\section{? TROUBLESHOOTING}




\section{TROUBLESHOOTING}

Troubleshooting advice can be found in Table 5.

\section{ANTICIPATED RESULTS}

Cellular membrane affinity chromatography has been used to characterize binding sites, in drug discovery as well as drug development. The characterization of a binding site is carried out through FAC or NLC. In the former case, a typical frontal chromatogram is illustrated in Figure 1a, where an initial flat portion represents the binding of the marker ligand to the immobilized protein, followed by saturation that is represented by a breakthrough and then a plateau ${ }^{8}$. In NLC (Fig. 1b), the observed concentration-dependent asymmetry is analyzed using chemometric curve-fitting techniques.

The protocol provided for the isolation of a target protein and its subsequent immobilization onto the IAM stationary phase will provide guidance for the immobilization of a variety of transmembrane domains. Typically, a standard IAM-PC column contains picomolar amounts of active binding sites for the immobilized protein, depending on the source and solubility of the target protein.

\section{ACKNOWLEDGMENTS}

This work was funded by the Intramural Research Program of the National Institute on Aging/NIH.

\section{References}

1. Ng ESM, Chora NWC, Lewis DF, Hindsgaul O, Schriemer D. Frontal affinity chromatographymass spectrometry. Nat. Protoc. 2007; 2:1907-1917. [PubMed: 17703202]

2. Chaiken IM. Analytical affinity chromatography in studies of molecular recognition in biology: a review. J. Chromatogr. 1986; 376:11-32. [PubMed: 3519631]

3. Wade JL, Bergold AF, Carr PW. Theoretical description of nonlinear chromatography, with applications to physicochemical measurements in affinity chromatography and implications for preparative-scale separations. Anal. Chem. 1987; 59:1286-1295.

4. Kim HS, Kye YS, Hage DS. Development and evaluation of N-hydroxysuccinimide-activated silica for immobilizing human serum albumin in liquid chromatography columns. J. Chromatogr. A. 2004; 1049:51-61. [PubMed: 15499917]

5. Moaddel R, et al. Automated ligand fishing using HSA-coated magnetic beads. Anal. Chem. 2007; 79:5414-5417. [PubMed: 17579480]

6. Brekkan E, Lundqvist A, Lundahl P. Immobilized membrane vesicle or proteoliposome affinity chromatography. Frontal analysis of interactions of cytochalasin B and D-glucose with the human red cell glucose transporter. Biochemistry. 1996; 35:12141-12145. [PubMed: 8810921]

7. Yang Q, Lundahl P. Immobilized proteoliposome affinity chromatography for quantitative analysis of specific interactions between solutes and membrane proteins. interaction of cytochalasin B and D-glucose with the glucose transporter Glut1. Biochemistry. 1995; 34:7289-7294. [PubMed: 7779771]

8. Zhang Y, Xiao YX, Kellar KJ, Wainer IW. Immobilized nicotinic receptor stationary phase for online liquid chromatographic determination of drug-receptor affinities. Anal. Biochem. 1998; 264:22-25. [PubMed: 9784183]

9. Pidgeon, C.; Marcus, C.; Alvarez, F. Applications of Enzyme Biotechnology. Baldwin, TO.; Kelly, JW., editors. Plenum Press; New York: 1992. 
10. Besanger TR, Hodgson RJ, Green JRA, Brennan JD. Immobilized enzyme reactor chromatography: optimization of protein retention and enzyme activity in monolithic silica stationary phases. Analytica. Chimica. Acta. 2006; 564:106-115. [PubMed: 17723368]

11. Beigi F, Wainer IW. Syntheses of immobilized G protein-coupled receptor chromatographic stationary phases: characterization of immobilized mu and kappa opioid receptors. Anal. Chem. 2003; 75:4480-4485. [PubMed: 14632053]

12. Beigi F, Chakir K, Xiao R-P, Wainer IW. G-protein-coupled receptor chromatographic stationary phases. 2. Ligand-induced conformational mobility in an immobilized beta2-adrenergic receptor. Anal. Chem. 2004; 76:7187-7193. [PubMed: 15595859]

13. Moaddel R, Calleri E, Massolini G, Frazier C, Wainer IW. The synthesis and initial characterization of an immobilized purinergic receptor (P2Y1) liquid chromatography stationary phase for on line screening. Anal. Biochem. 2007; 364:216-218. [PubMed: 17391632]

14. Moaddel R, Jozwiak K, Whittington KC, Wainer IW. The on-line determination of agonists/ competitive antagonists and non-competitive inhibitors of the $\alpha 3 \beta 2, \alpha 3 \beta 4, \alpha 4 \beta 2$, and $\alpha 4 \beta 4$ nicotinic acetylcholine receptors using immobilized receptor-based liquid chromatographic stationary phases. Anal. Chem. 2005; 77:895-901. [PubMed: 15679359]

15. Zhang Y, Leonessa F, Clarke R, Wainer IW. Development of an immobilized P-glycoprotein stationary phase for on-line liquid chromatographic determination of drug-binding affinities. J. Chromatogr. B. 2000; 739:33-37.

16. Moaddel R, Yamaguchi R, Ho P, Patel S, Wainer IW. Development and characterization of the human organic cation transporter column. J. Chrom. B. 2005; 818:263-268.

17. Kimura T, Perry J, Anzai N, Pritchard J, Moaddel R. Development and characterization of immobilized human organic anion transporter based liquid chromatographic stationary phase: hOAT1 and hOAT2. J. Chrom. B. 2007; 859:267-271.

18. Moaddel R, Cloix JF, Ertem G, Wainer IW. Multiple receptor liquid chromatographic stationary phases: development of a co-immobilized nicotinic receptor, GABA receptor and NMDA receptor stationary phase. Pharm. Res. 2002; 19:104-107. [PubMed: 11837693]

19. Moaddel R, Bullock P, Wainer IW. Development and characterization of an open tubular column containing immobilized P-glycoprotein for rapid on-line screening for P-glycoprotein substrates. J. Chrom. B. Analyt. Technol. Biomed. Life Sci. 2004; 799:255-263.

20. Maciuk A, Moaddel R, Haginaka J, Wainer IW. Screening of tobacco smoke condensate for nicotinic acetylcholine receptor ligands using cellular membrane affinity chromatography columns and missing peak chromatography. J. Pharm. Biomed. Anal. 2008; 48:238-246. [PubMed: 18187282]

21. Moaddel R, et al. On-line screening of conformationally constrained nicotines and anabasines for agonist activity at the $\alpha 3 \beta 4$ and a4 32 -nicotinic acetylcholine receptors using immobilized receptor based liquid chromatographic stationary phases. J. Chrom. B. 2004; 813:235-240.

22. Moaddel R, Jozwiak K, Wainer IW. Allosteric modifiers of neuronal nicotinic acetylcholine receptors: new methods, new oppurtunities. Med. Res. Rev. 2007; 27:723-753. [PubMed: 17238157]

23. Moaddel R, Hamid R, Patel S, Wainer IW, Bullock P. Comparison of an open tubular column containing immobilized P-glycoprotein with Caco-2 cell monolayers for the purpose of investigating interactions between drug candidates and Pgp. Anal. Chimica. Acta. 2006; 578:2530.

24. Moaddel R, Ravichandran S, Bighi F, Yamaguchi R, Wainer IW. The Prediction and description of stereoselective binding to the human organic cation transporter (hOCT1). Brit. J. Pharm. 2007; 151:1305-1314.

25. Jozwiak K, Hernandez SC, Kellar KJ, Wainer IW. Enantioselective interactions of dextromethorphan and levomethorphan with the a3 $\beta 4$-nicotinic acetylcholine receptor: comparison of chromatographic and functional data. J. Chromatogr. B. 2003; 797:373-379.

26. Jozwiak K, Ravichandran S, Collins J, Moaddel R, Wainer IW. Interaction of noncompetitive inhibitors of the a $3 \beta 2$ nicotinic acetylcholine receptor investigated by affinity chromatography and molecular docking. J. Med. Chem. 2007; 50:6279-6283. [PubMed: 17973360] 
27. Kitabatake T, et al. Characterization of a multiple ligand-gated ion channel cellular membrane affinity chromatography (CMAC) column and identification of endogenously expressed receptors in astrocytoma cell lines. Anal. Chem. 2008; 80:8673-8680. [PubMed: 18847217]

28. Moaddel R, et al. Initial synthesis and characterization of an a7 nicotinic receptor cellular membrane affinity chromatography column: effect of receptor subtype and cell type. Anal. Chem. 2008; 80:48-54. [PubMed: 18062706]

29. Leonessa F, et al. Effect of tamoxifen on the multidrug-resistant phenotype in human breast cancer cells: isobologram, drug accumulation, and M(r) 170,000 glycoprotein (gp170) binding studies. Cancer Res. 1994; 54:441-447. [PubMed: 7903910]

30. Walsch, CT. Posttranslational Modifications of Proteins: Expanding Nature's Inventory. Roberts and Co.; Greenwood, CO, USA: 2007.

31. Wade L, Bergold AF, Carr PW. Theoretical description of nonlinear chromatography, with applications to physicochemical measurements in affinity chromatography and implications for preparative-scale separations. Anal. Chem. 1986; 59:1286-1295.

32. Baynham MT, Patel S, Moaddel R, Wainer IW. Multidimensional on-line screening for ligands to the a3 34 neuronal nicotinic acetylcholine receptor using an immobilized nicotinic receptor liquid chromatographic stationary phase. J. Chrom. B. 2002; 772:155-61.

33. Moaddel R, et al. Automated ligand fishing using HSA-coated magnetic beads. Anal. Chem. 2007; 79:5414-5417. [PubMed: 17579480]

34. Marszall M, et al. Ligand and protein fishing with heat shock protein 90 coated magnetic beads. Anal. Chem. 2008; 80:7571-7575. [PubMed: 18693748]

35. Cleland JL, et al. A specifc molar ratio of stabilizer to protein is required for storage stability of a lyophilized monoclonal antibody. J. Pharm. Sci. 2000; 90:310-321. [PubMed: 11170024] 


\section{BOX 1}

\section{IMMOBILIZATION ON OPEN TUBULAR CAPILLARIES}

Open tubular capillary $\bullet$ TIMING $\sim 4-5 \mathrm{~d}$

(i) Pass a solution of $1 \mathrm{M} \mathrm{NaOH}$ through a fused silica capillary $(25 \mathrm{~cm} \times 100 \mu \mathrm{m}$

i.d.) for $30 \mathrm{~min}$ at $50 \mu \mathrm{lmin}-1$ followed by water for $15 \mathrm{~min}$ and then air for $5 \mathrm{~min}$.

(ii) Incubate the capillary at $95^{\circ} \mathrm{C}$ for $1 \mathrm{~h}$.

(iii) Pass an aqueous solution of 90:10 (vol/vol) water:amino propyl trimethoxy silane (APTS) through the capillary for $5 \mathrm{~min}$ at $50 \mu \mathrm{min}^{-1}$, then incubate in the oven at $95^{\circ} \mathrm{C}$ for $30 \mathrm{~min}$

(iv) Repeat Step (iii) and leave the capillary open to air overnight.

(v) The following morning, pass a $1 \%$ gluteraldehyde solution in phosphate buffer (50 mM, pH 7.4) through the capillary for $60 \mathrm{~min}$ at $50 \mu \mathrm{l} \mathrm{min}{ }^{-1}$ followed by $250 \mu \mathrm{l}$ of water and then recycle a solution of avidin ( $10 \mathrm{mg}$ in $2 \mathrm{ml}$ of phosphate buffer (50 $\mathrm{mM}, \mathrm{pH}$ 7.4)) through the capillary for $4 \mathrm{~h}$.

(vi) Submerge both tips of the capillary in the avidin solution for $5 \mathrm{~d}$.

(vii) Then, run a solution of biotin-X (14 mM in 3:1 (vol/vol) DMSO:phosphate buffer (50 mM, pH 7.4)) through the capillary for $30 \mathrm{~min}$ at $50 \mu \mathrm{min}^{-1}$ and submerge both tips of the capillary in the solution overnight.

\section{Derivatize membranes @ TIMING 2d}

(viii) Prepare the homogenization and solubilization buffers as described previously in the section on homogenization and solubilization (Procedure Steps 1-5).

However, only use $2 \mathrm{ml}$ of the solubilization buffer.

\section{Dialysis $\bigcirc$ TIMING 1-3 d}

(ix) Pass the solubilized membranes through the capillary for $3 \mathrm{~h}$ at $10 \mu \mathrm{min} \mathrm{m}^{-1}$. Subsequently, cap the open tubular capillary on both ends with dialysis membrane, secure using copper wires and place in a glass beaker containing the dialysis buffer (Tris buffer (10 mM, pH 7.4) containing $150 \mathrm{mM} \mathrm{NaCl}, 1.0 \mathrm{mM}$ EDTA, $1.0 \mathrm{mM}$ benzamidine). Place the beaker in a cold room at $4{ }^{\circ} \mathrm{C}$ and rotate overnight at 110 r.p.m. on an orbital shaker.

(x) The following day, repeat Step (ix).

(xi) On the third day, rinse the column for a few hours at a low flow rate (about 1-5 $\mu \mathrm{l} \mathrm{min}{ }^{-1}$ ). It should be noted that multiple other methods were attempted to remove the detergent, including rinsing at low flow rates; however, none resulted in a functional column.

(xii) Attach the column to a Shimadzu LC-10Advp pump (Shimadzu Corp.) through a fitting with TFE Teflon tubing $(0.3 \mathrm{~mm}$ i.d. $\times 1.58 \mathrm{~mm}$ o.d.) from Supelco and equilibrate by rinsing the column with ammonium acetate $(10 \mathrm{mM}, \mathrm{pH} 7.4)$ for $1 \mathrm{~h}$ at $50 \mu \mathrm{l} \mathrm{min}{ }^{-1}$. 
(xiii) Proceed from Step 10 of the main PROCEDURE.

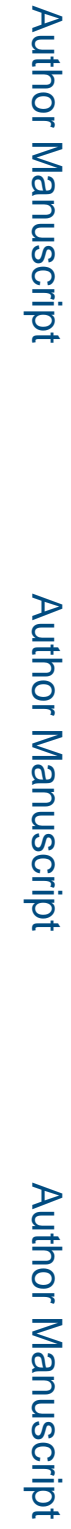

Nat Protoc. Author manuscript; available in PMC 2015 October 14. 

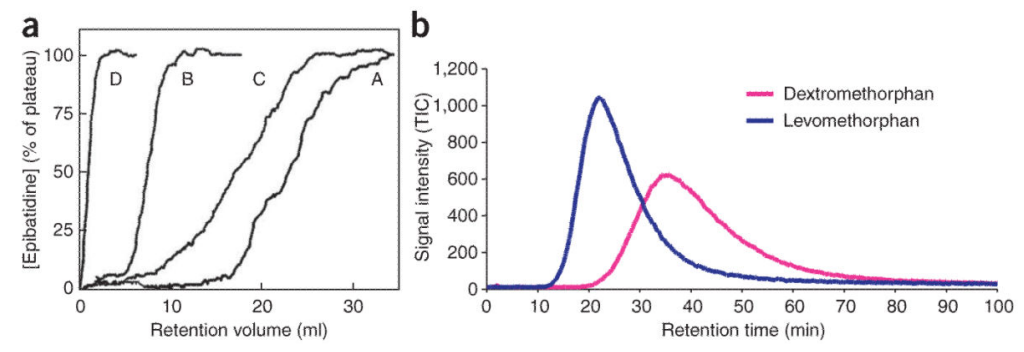

Figure 1.

Typical Frontal and Non-Linear chromatograms. (a) The elution profiles of $\left[{ }^{3} \mathrm{H}\right]$-epibatidine on a3 34 NR-IAM column $(0.5 \mathrm{~cm} \times 1.7 \mathrm{~cm})$ at $0.4 \mathrm{ml} \mathrm{min}{ }^{-1}$, where $\mathrm{A}=60 \mathrm{pM}, \mathrm{B}=450$ $\mathrm{pM}, \mathrm{C}=60 \mathrm{pM}\left[{ }^{3} \mathrm{H}\right]$-epibatidine in the presence of $60 \mathrm{nM}(-)$-nicotine; $\mathrm{D}=60 \mathrm{pM}\left[{ }^{3} \mathrm{H}\right]$ epibatidine in the presence of 1,000 nM (-)-nicotine. Reproduced from ref. 8 with permission from Elsevier. (b) The comparison of peak profiles of dextromethorphan (pink) and levomethorphan (blue) obtained in independent experiments on the a3 $\beta 4$ NR-IAM column $(0.5 \mathrm{~cm} \times 0.8 \mathrm{~cm})$ at $0.2 \mathrm{ml} \mathrm{min}^{-1}$. Reproduced from ref. 25 with permission from Elsevier. 


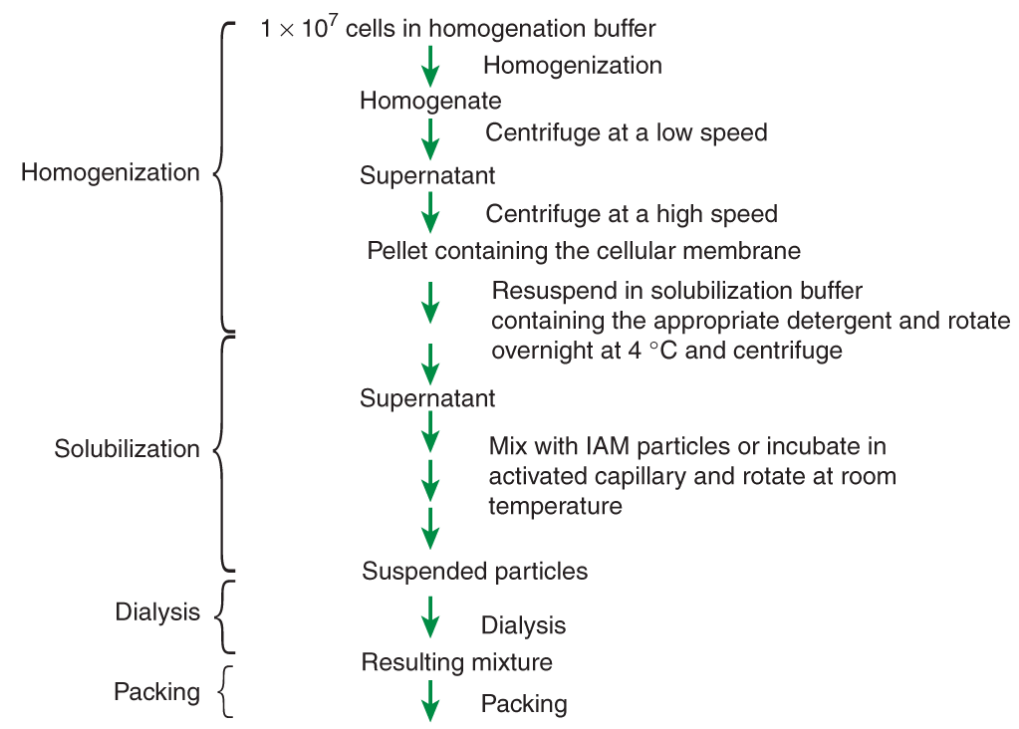

Figure 2.

Flowchart for the immobilization process. 


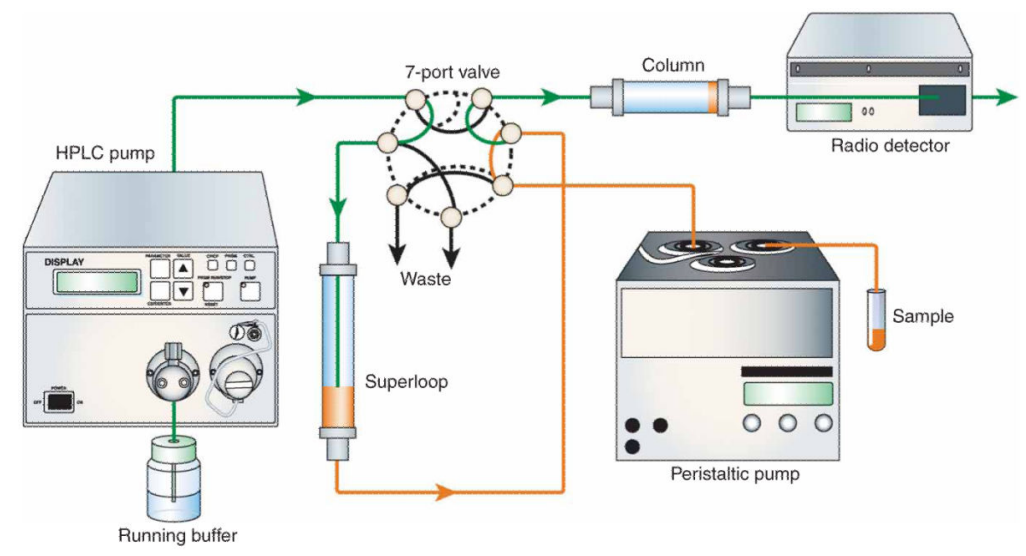

Figure 3 .

Chromatographic system. 


\section{TABLE 1}

\section{Key parameters for preparing columns.}

\begin{tabular}{|c|c|}
\hline Source & $\begin{array}{l}\text { The ideal source is a transfected cell line containing the target protein. In this way, a column containing a significant amount } \\
\text { of the target protein can easily be obtained } \\
\text { For a multiple protein column, untransfected cells or tissue can be used } \\
\text { We have used a number of cell lines including HEK-293, SH-EP1, MDCK, LCC6, astrocytomas, gliomas and CHO-CAR }\end{array}$ \\
\hline $\begin{array}{l}\text { Amount of } \\
\text { cells/tissue }\end{array}$ & $\begin{array}{l}\text { About } 4 \mathrm{~g} \text { of tissue is sufficient to obtain a functioning column } \\
\text { The number of cells is dependent on the level of expression of the target protein in the transfected or nontransfected cell. } \\
\text { We have used as little as } 1 \text { million cells (HEK-293 a3 } 34 \text { cells) to as much as } 100 \text { million cells for Pgp }\end{array}$ \\
\hline $\begin{array}{l}\text { Protease } \\
\text { inhibitors }\end{array}$ & $\begin{array}{l}\text { Dependent on cell type or tissue, e.g., HEK-293: leupeptin, pepstatin, PMSF and benzamidine } \\
\text { SH-EP1 cells: leupeptin, PMSF and benzamidine } \\
\text { 1321N1: benzamidine, PMSF, aprotinin, leupeptin and TPCK } \\
\text { Torpedo membranes: calpain I and II, aprotinin, leupeptin, pepstatin, benzamidine and PMSF }\end{array}$ \\
\hline Cofactors & $\begin{array}{l}\text { In certain cases, the addition of cofactors are necessary for proper functioning of the column } \\
\text { For example, } \\
\text { NMDA: glutamate and glycine } \\
\text { Pgp: ATP is needed to study the second cat. state } \\
\text { Nicotinic receptors: none required } \\
\text { These cofactors are needed in the mobile phase during the chromatographic run; in the case of } \mathrm{P}_{2} \mathrm{Y}_{1} \text {, it is required in } \\
\text { the solubilization buffer }\end{array}$ \\
\hline $\begin{array}{l}\text { Lipids/ } \\
\text { cholesterol }\end{array}$ & $\begin{array}{l}\text { In some cases, the addition of lipids and/or cholesterol is necessary for proper function of the channel. This has been } \\
\text { shown to be dependent on the cell type and receptor type } \\
\text { For example, } \\
\text { HEK-a3 } \beta 4 \text { nicotinic receptor does not require the addition of any lipids and cholesterol } \\
\text { HEK-a7 requires the addition of cholesterol } \\
\text { SH-EP1 a } 7 \text { requires the addition of PS, PE and cholesterol }\end{array}$ \\
\hline Detergents & $\begin{array}{l}\text { Use mild detergents with low aggregate number per micelle, and high CMC. For example, mild detergents, such as CHAPs } \\
\text { and cholate, are ideal, whereas others, such as Triton X-100, are too strong and are very difficult to remove, i.e., they require the } \\
\text { use of bio-beads } \\
\text { CHAPS-GPCRs and transporters } \\
\text { Cholate-LGIC } \\
\beta \text {-Octylglucopyranoside-LGIC/GPCR, transporters }\end{array}$ \\
\hline Dialysis & $\begin{array}{l}\text { Dependent on protein stability in solution } \\
\text { For example, at } 4{ }^{\circ} \mathrm{C}, \\
\text { a } 7 \text { nicotinic receptor, } 1 \mathrm{~d} \\
\text { PGP, } 1 \mathrm{~d} \\
\text { hOCT } 1,2 \mathrm{~d} \\
\text { hOAT } 1,2 \mathrm{~d} \\
\text { a3ß4 nicotinic receptor } \times 2 \mathrm{~d}\end{array}$ \\
\hline
\end{tabular}




\section{TABLE 2}

\section{Immobilization of isolated membranes.}

Immobilization Immobilization artificial monolayer (IAM)-PC: we use this stationary phase for the majority of our transmembrane technique proteins. However, the substrates/ligands should not be highly lipophilic. For example, this is an ideal stationary phase for proteins. However, the substrates/ligands should not
the nicotinic receptor, as all the ligands are charged

$\mathrm{Pgp}$, on the other hand, has highly lipophilic substrates, making it very difficult to run on the IAM stationary phase

Open-tubular glass: this is an alternative to the IAM-PC stationary phase and is based on the avidin-biotin system with a lipophilic arm. This has worked well with the Pgp transporter

Running buffer Typically, we start with $10 \mathrm{mM}$ ammonium acetate

This ionic strength is sufficient for the proper function of the immobilized protein. If you have problems with

protein stability/reproducibility, this can be augmented to $50 \mathrm{mM}$ ionic strength. The addition of an organic (methanol) modifier can be used to reduce the retention time and increase throughput. However, close attention should be paid to the effects of organic modifiers on the protein function/stability

The addition of salts is at times necessary for the proper functioning of the protein. For example, the hOCT1 requires the addition of $\mathrm{MgCl}_{2}$ 
TABLE 3

Analysis of columns.

\begin{tabular}{ll}
\hline $\begin{array}{l}\text { Frontal } \\
\text { chromatography }\end{array}$ & $\begin{array}{l}\text { Frontal affinity chromatography is used to } \\
\text { determine the binding affinity of a ligand for the } \\
\text { immobilized protein. The frontal regions are com- } \\
\text { posed of an initial flat portion that represents the } \\
\text { specific binding of the marker ligand followed by a } \\
\text { breakthrough curve indicating saturation of the } \\
\text { protein, ending in a plateau }\end{array}$ \\
$\begin{array}{l}\text { Nonlinear } \\
\text { chromatography }\end{array}$ & $\begin{array}{l}\text { NLC theory applies primarily to zonal affinity } \\
\text { chromatography. In this approach, the injections } \\
\text { of finite concentrations of a ligand produce }\end{array}$ \\
& $\begin{array}{l}\text { asymmetric peak profiles with tailing proportional } \\
\text { to the ligand concentrations. The model assumes a } \\
\text { limited number of active sites on the column and a } \\
\text { nonlinear isotherm }\end{array}$ \\
Retectors & $\begin{array}{l}\text { Radio-flow detector, mass spectrometry, detector } \\
\text { and UV detector }\end{array}$ \\
\hline
\end{tabular}


TABLE 4

The advantages and disadvantages of each chromatographic approach.

\begin{tabular}{lll}
\hline & Best for & Limitations \\
\hline FAC & $\begin{array}{l}\text { Determining binding } \\
\text { affinities (Kd and Kis) } \\
\text { for single or multiple } \\
\text { compounds }\end{array}$ & $\begin{array}{l}\text { Cannot determine } \\
\text { binding kinetics }\end{array}$ \\
NLC & $\begin{array}{l}\text { Determing binding kinetics } \\
\text { (kon and koff) and for } \\
\text { studying allosteric } \\
\text { modifiers }\end{array}$ & $\begin{array}{l}\text { Long chromatographic } \\
\text { run times }\end{array}$ \\
$\begin{array}{l}\text { Zonal } \\
\text { chromatography }\end{array}$ & $\begin{array}{l}\text { Affinity separation and } \\
\text { fanking of compounds } \\
\text { from complex mixtures }\end{array}$ & Low capacity \\
Magnetic beads & $\begin{array}{l}\text { Ligand fishing/protein } \\
\text { fishing }\end{array}$ & $\begin{array}{l}\text { Cannot be used to } \\
\text { determine kinetic data } \\
\text { or binding affinities }\end{array}$ \\
\hline
\end{tabular}




\section{TABLE 5}

Troubleshooting table.

\begin{tabular}{|c|c|}
\hline How many cells? & $\begin{array}{l}\text { If repeated attempts to immobilize the protein have failed, and the number of cells has been increased by at least one order } \\
\text { of } \\
\text { magnitude (preferably two), then the problem may not be with the number of cells but rather with the stability of the } \\
\text { protein } \\
\text { during the immobilization process. Please remember that there is a threshold at which point increasing the number of cells } \\
\text { will } \\
\text { not help and may in fact hinder the successful immobilization of the target protein. To determine how much of the target } \\
\text { protein } \\
\text { has been immobilized, it is recommended that the stationary phase containing the target protein is stripped, followed by } \\
\text { western blot analysis. If the protein is present and nonfunctional, either too small an amount was immobilized, making it } \\
\text { undetectable, or the protein was immobilized in a nonfunctional state. In the former case, it is recommended to increase the } \\
\text { number of cells. If this fails, then isolation of the target protein through affinity chromatography is recommended }\end{array}$ \\
\hline $\begin{array}{l}\text { Homogenization } \\
\text { and } \\
\text { solubilization }\end{array}$ & $\begin{array}{l}\text { If the protein is immobilized in a nonfunctional state, it is suggested that an agonist/competitive antagonist for the target } \\
\text { protein is added to the homogenization and solubilization buffer (with the addition of glycerol in the solubilization buffer) } \\
\text { to } \\
\text { keep the proper conformation of the protein throughout the immobilization process } \\
\text { Another possibility is that the protein is susceptible to oxidation; in this case, the addition of 1-5 mM DTT or } \beta \text { - } \\
\text { mercaptoethanol to } \\
\text { the homogenization and solubilization buffer is recommended to keep the protein in the reduced state. The addition of } \\
\text { EDTA or EGTA } \\
\text { is also recommended to help keep the protein in the reduced state in addition to their role as a metalloprotease inhibitor }\end{array}$ \\
\hline Dialysis & $\begin{array}{l}\text { Initially the dialysis should be carried out over a period of } 2 \mathrm{~d} \text {. If the resulting column is not functional and the possibility } \\
\text { of } \\
\text { insufficient protein, the absence of necessary protease inhibitor and an inappropriate detergent for the target protein have } \\
\text { been } \\
\text { ruled out, then the protein may not be stable under the dialysis conditions for longer times }(2-3 \mathrm{~d}) \text {. Therefore, it is } \\
\text { recommended } \\
\text { in these cases that the dialysis time be reduced to } 1 \mathrm{~d} \\
\text { If, following dialysis and packing of the columns, the retention of the marker is not reproducible (it moves to the right for } \\
\text { successive runs), this indicates that the dialysis time was too short and that there was a significant amount of detergent that } \\
\text { remained on the stationary phase. To correct this problem, the column can be washed at a low flow rate for a few hours, } \\
\text { and } \\
\text { subsequent immobilizations should increase the dialysis time by } 18 \mathrm{~h}\end{array}$ \\
\hline
\end{tabular}

